\title{
THE DIMENSIONS OF THE MANAGERIAL THINKING STRATEGIC SCHOOLS AND THEIR DEFFINITORY CHARACTERISTICS FOR ELABORATING THE STRATEGY
}

\author{
Assistant professor PhD Student Mălina Cordoş, malina_cordos@yahoo.com \\ "1 Decembrie 1918 ,Faculty of Science
}

\begin{abstract}
What is strategy? We can say with certitude there is no unique universally accepted definition. The specialized literature is rich in studies, books and perspectives over the strategy, but this abundance proves the relevance and the complexity of this subject. And this complexity makes it hard to find a single good answer in developing a strategy. As Whittington (2001) said, the different conceptions about the strategy have radically different implications over the strategy's elaboration process ${ }^{\text {. }}$.

Henry Mintzberg identified 10 schools of managerial thinking - three prescriptive and seven descriptive. In this article I will try to make some considerations regarding the dimensions of these schools and their deffinitory characteristics for elaborating the strategy.
\end{abstract}

The theme that refers to the strategy of the organization has concerned a series of the management's personalities, the most representative being: Harry Igor Ansoff, Alfred D. Chandler, Kenichi Ohmae and Michael E.Porter.

Henry Mintzberg, the famous expert, has identified 10 schools for managerial thinking - three prescriptive (based on customs) and seven descriptive ${ }^{2}$ :

- Design (denotes a conception process) - the original conception belonged to Selznick (1957), followed by the one of Alfred Chandler (1962) and then by an Andrews (1965) definition - who sees strategy as being the achievement of an exact match between the strong and the weak points inside the organization and between the external threats and opportunities. The superior management defines clear, simple and unique strategies through a deliberate thinking process which is not formal-analytical, nor informal-intuitive - so everybody can implement the strategy. This was the dominant outlook on strategies in the 70's, though the design school did not develop to give birth to its variants, specific for the context.

- Planning (denotes a formal process) - this school developed parallel with the design school. It was predominant in the middle 70's and started to decline in the 80 's, but today it continues to be an important branch in the specialized literature. Ansoff (1965) emphasized that the process is not only cerebral, but formal, and it can be divided in distinct steps, shaped through checklists and sustained by technology (especially when it comes to objectives, budgets, operational

\footnotetext{
${ }^{1}$ R. Whittington - What Is Strategy?- and Does It Matter, 2nd Edition, Thomson Learning, London, 2001, p. 325

${ }^{2}$ H. Mintzberg, J. Lampel, J.B. Quinn, S. Goshal, The strategy process, Fourth Edition, Pearson Education International, 2003, p.22-26
} 
programs and plans). This means superior managers were replaced by the planning personnel as main stars in this process.

- Positioning (denotes an analytical process) - the third prescriptive school, it represented the predominant vision in forming strategies in the 80's. The impelling of this school was generated especially by Michael Porter because of his approach regarding the strategic positioning and because of his approach in the consulting field (The Boston Consulting Group, through the PIMS Project Project Impact of Market Strategies). In their vision the strategy is reduced to the generic position selected through formalized analysis. This way the people who plan become analysts. These aspects turned out to be profitable especially for consultants and for the academic environment who managed to promote the "scientific truth" through magazines and companies. Thus, the specialized literature started to develop in all directions, touching subjects like strategic groups, value chains, games theory, all with a powerful analytical trend.

\& Entrepreneurial (has at its base a visionary process) - the entrepreneurial school sets in its centre the executive management almost like the design school. But, unlike the design school and at the other pole from the planning school, the entrepreneurial school ties this process of intuition. This orientation shifts the strategy from a precise design, from plans and positions to vague visions or large perspectives that are often seen as metaphorical. In this vision the leader has a tied control over the implementation of the formulated vision.

- Cognitive (denotes a mental process) - research has evolved gradually to the cognitive aspects of the strategy, to the "mapping" of the knowledge' structure, especially in the 80's and continuing today. These were the last wordings regarding the strategy's elaboration and at the same time they had a minimum progress. In the mean time, other branches of this school adopted more subjective, interpretative, or constructivist visions over the strategy's process in which the cognition is used to build strategies as creative interpretations, not just to identify reality in a more or less subjective manner.

- Learning (denotes an emergent process) - from the descriptive schools the learning school has transformed in a real wave and brought big challenges at the expense of the prescriptive schools. In this perspective the strategies are emergent (unexpected).

- Power (denotes a negotiation process) - in this case there are two different directions: at the micro level the power sees the strategy's developing from the inside of the organization as being of a profound political nature - a process that implies bargain, persuasion and confrontation between actors that divide the power among them. The power at a macro level sees the organization as an entity that uses its power over partners, joint-ventures or other network type relations in order to negotiate collective strategies that are in their own interest.

- Cultural (it refers to a social process) - this school is based on formulating the strategy as a social process with deep routs in culture. The specialized literature is focused especially on the influence of the culture in discouraging significant strategic changes. Culture has become something to talk about in the American specialized literature after the impact of the Japanese management, which was at its peak in the 80 's. 
Environmental (it represents a reactive process) - in the context of this school we can talk about the so-called "Contingency theory", which focuses on the answers that are expected from the environment regarding the special environment conditions. Another theory is the "Institutional theory" which is aimed at the institutional pressures over the organization.

\& Configurative (it's represented by a transformation process) - it sees the organization as a configuration - a bundle of coherent characteristics and behaviors. The configurative school also integrates the characteristics of the other schools and each configuration has a well determined place. Planning, for example, is predominant in the mechanical type of organizations in relative stable conditions, while entrepreneurial can be found in more dynamic configurations.

In chart no. 1 synthetically presents these schools and their definitive features in elaborating a strategy:

Chart 1. The dimenssions of the 10 strategic school (source: H. Mintzberg, J. Lampel, J.B. Quinn, S. Goshal, The Strategy Process, Fourth Edition, Pearson Education International, 2003, p.24-25)

\begin{tabular}{|c|c|c|c|c|c|}
\hline & \multicolumn{5}{|c|}{ The name of the school } \\
\hline & Design & \begin{tabular}{|l|} 
Planning \\
\end{tabular} & Positioning & Entrepreneurial & Cognitive \\
\hline Source & \begin{tabular}{|l|} 
P.Szelnik, \\
K.R.Andrews
\end{tabular} & H. Ansoff & \begin{tabular}{|l|} 
D.E..Schendel, \\
K.J.Hatten, \\
M.Porter \\
\end{tabular} & $\begin{array}{l}\text { J. Schumpeter, A. } \\
\text { Cole }\end{array}$ & $\begin{array}{l}\text { H.A. Simon, } \\
\text { J.G.March }\end{array}$ \\
\hline $\begin{array}{l}\text { The basic } \\
\text { branch of } \\
\text { science }\end{array}$ & None & $\begin{array}{l}\text { Some are tied } \\
\text { to urban } \\
\text { planning, } \\
\text { system theory, } \\
\text { cybernetics }\end{array}$ & $\begin{array}{l}\text { Economic } \\
\text { science and } \\
\text { military history }\end{array}$ & $\begin{array}{l}\text { None (even if the } \\
\text { first tries belong to } \\
\text { the economic field) }\end{array}$ & $\begin{array}{l}\text { Psychology } \\
\text { (cognitive) }\end{array}$ \\
\hline Promoters & $\begin{array}{l}\text { Professors } \\
\text { focused on } \\
\text { case studies, } \\
\text { especially in } \\
\text { the United } \\
\text { States of } \\
\text { America }\end{array}$ & $\begin{array}{l}\text { Managers, } \\
\text { MBA experts, } \\
\text { expert workers } \\
\text { (especially in } \\
\text { the finance } \\
\text { field), } \\
\text { consultants and } \\
\text { governmental } \\
\text { control } \\
\text { institutions } \\
\text { especially in } \\
\text { France and } \\
\text { USA } \\
\end{array}$ & $\begin{array}{l}\text { Expert } \\
\text { workers, } \\
\text { consultants, } \\
\text { writers from } \\
\text { the military } \\
\text { field, } \\
\text { especially in } \\
\text { the USA }\end{array}$ & $\begin{array}{l}\text { Business press, } \\
\text { small businesses, } \\
\text { individuals, } \\
\text { especially in Latin } \\
\text { America and China }\end{array}$ & $\begin{array}{l}\text { People with } \\
\text { inclinations } \\
\text { for } \\
\text { psychology } \\
\text { - pessimists } \\
\text { on one hand } \\
\text { and } \\
\text { optimists on } \\
\text { the other } \\
\text { hand }\end{array}$ \\
\hline $\begin{array}{l}\text { The } \\
\text { intended } \\
\text { message }\end{array}$ & Matching & Formalization & Analysis & Vision & Creation \\
\hline $\begin{array}{l}\text { The } \\
\text { achieved } \\
\text { message }\end{array}$ & Thinking & Programming & Calculus & Centralization & Concern \\
\hline Type of & Prescriptive & Prescriptive & Prescriptive & Descriptive & Descriptive \\
\hline
\end{tabular}




\begin{tabular}{|c|c|c|c|c|c|}
\hline sch & & & & & \\
\hline $\begin{array}{l}\text { An } \\
\text { associated } \\
\text { proverb }\end{array}$ & $\begin{array}{l}\text { „Look before } \\
\text { you jump" }\end{array}$ & $\begin{array}{l}\text { "A stitch in } \\
\text { time } \\
\text { nine" }\end{array}$ & $\begin{array}{l}\text { „Nothin' } \begin{array}{l}\text { but } \\
\text { the } \\
\text { ma'am” }\end{array} \\
\text { facts, }\end{array}$ & $\begin{array}{l}\text { "Take us to be } \\
\text { your leaders" }\end{array}$ & $\begin{array}{l}\text { "I'll believe } \\
\text { it when I } \\
\text { see it” }\end{array}$ \\
\hline
\end{tabular}

\begin{tabular}{|c|c|c|c|c|c|}
\hline & \multicolumn{5}{|c|}{ The name of the school } \\
\hline & Learning & Power & Cultural & Environmental & Configurative \\
\hline Source & $\begin{array}{l}\text { C.E.Lindblom, } \\
\text { L.M. Cyert, } \\
\text { J.G.March, } \\
\text { J.B.Quinn } \\
\text { G.Hamel }\end{array}$ & $\begin{array}{l}\text { G.T.Allison, } \\
\text { J.Pfeffer, } \\
\text { W.G.Astley }\end{array}$ & $\begin{array}{l}\text { E.Rhenman, } \\
\text { R.Normann } \\
\text { (Suedia) }\end{array}$ & $\begin{array}{l}\text { M.T.Hahhan, } \\
\text { J.Freeman }\end{array}$ & $\begin{array}{l}\text { A.D.Chandler, } \\
\text { H.Mintzberg, } \\
\text { D.Miller, } \\
\text { R.E.Milles, } \\
\text { C.Snow }\end{array}$ \\
\hline $\begin{array}{l}\text { The basic } \\
\text { branch of } \\
\text { science }\end{array}$ & $\begin{array}{l}\text { None (maybe } \\
\text { only a few } \\
\text { peripherical } \\
\text { connections } \\
\text { with the } \\
\text { Learning } \\
\text { theory from } \\
\text { psychology } \\
\text { and education, } \\
\text { The Chaos } \\
\text { Theory in } \\
\text { mathematics) }\end{array}$ & $\begin{array}{l}\text { Political } \\
\text { science }\end{array}$ & Anthropology & Biology & History \\
\hline Promoters & $\begin{array}{l}\text { People with } \\
\text { inclinations for } \\
\text { experimenting, } \\
\text { ambiguity, } \\
\text { adaptability } \\
\text { (especially in } \\
\text { Japan and } \\
\text { Scandinavian } \\
\text { countries ) }\end{array}$ & $\begin{array}{l}\text { People who } \\
\text { enjoy power, } \\
\text { politics and } \\
\text { conspiracies, } \\
\text { especially in } \\
\text { France }\end{array}$ & $\begin{array}{l}\text { People with } \\
\text { social and } \\
\text { spiritual } \\
\text { inclinations, } \\
\text { with } \\
\text { collective } \\
\text { spirit, } \\
\text { especially in } \\
\text { Japan and } \\
\text { Scandinavian } \\
\text { countries }\end{array}$ & $\begin{array}{l}\text { Ecologists, } \\
\text { theoreticians } \\
\text { from the } \\
\text { organizational } \\
\text { field, especially } \\
\text { in the Anglo- } \\
\text { Saxon countries }\end{array}$ & $\begin{array}{l}\text { Integrators in } \\
\text { general, change } \\
\text { agents. A } \\
\text { concept that } \\
\text { was spread in } \\
\text { Holland and the } \\
\text { United States of } \\
\text { America }\end{array}$ \\
\hline $\begin{array}{l}\text { The } \\
\text { intended } \\
\text { message }\end{array}$ & Learning & Promotion & Fusion & Reaction & $\begin{array}{l}\text { Integration, } \\
\text { transformation }\end{array}$ \\
\hline $\begin{array}{l}\text { The } \\
\text { achieved } \\
\text { message }\end{array}$ & Game & Accumulation & Perpetuation & Capitulation & Combination \\
\hline $\begin{array}{l}\text { Type of } \\
\text { school }\end{array}$ & Descriptive & Descriptive & Descriptive & Descriptive & Descriptive \\
\hline $\begin{array}{l}\text { An } \\
\text { associated } \\
\text { proverb }\end{array}$ & $\begin{array}{l}\text { „If at first you } \\
\text { don't succeed, } \\
\text { try, try again" }\end{array}$ & $\begin{array}{l}\text { "Look to be } \\
\text { number one" }\end{array}$ & $\begin{array}{l}\text { "An apple } \\
\text { never falls far } \\
\text { from the tree" }\end{array}$ & „It all depends” & $\begin{array}{l}\text { There's a time } \\
\text { for everything }\end{array}$ \\
\hline
\end{tabular}


Henry Mintzberg tries to clarify if this school represent different processes in elaborating the strategy, or are different parts of the same process.

Thus, with the help of the first option, the author makes arguments by taking into consideration that some of the schools are just stages or aspects in formulating the strategy, as follows:

$>$ The cognitive school belongs to the strategists' vision, located in its centre

$>$ The positioning school looks behind and sets dates that are analyzed and kept in the „black box” of the strategy's elaboration

$>$ The planning school looks a little forward to program strategies

$>$ The design school looks further ahead in the future to a strategic perspective

$>$ The entrepreneurial school looks beyond a unique vision of the future

$>$ The learning and the power schools look under and get lost in details

$>$ The cultural school looks down and is under the imperative influence of faith

$>$ The configurative school looks at the process, more specifically at its exterior aspects

D The cognitive school tries to get inside the process.

As a conclusion, formulating the strategy is at the same time a long thought project, an intuitive vision, a learning in time process, but it also refers to transformation and to perpetuation; it implies individual knowledge and social interaction. At the same time it has a co-operative nature as well as a conflict nature, it must include analysis before, programming after and negotiation during the process; and all the things above must be in concordance with the specific conditions of the environment.

The arguments brought to sustain the second option (it approaches schools as parts of the same process) are the following:

$>$ Sometimes the process has to be more individual-cognitive then socialinteractive (for example in the case of small businesses)

$>$ Some strategies seem to be rather rational-deliberate (especially in matured mass industries), while others tend to be more emergent-adaptive (in the case of high-tech industries)

$>$ The environment is sometimes very solicited (in the case of social revolution), and other times (maybe even at the same time) the entrepreneurs can easily manage.

The schools that are seen as different parts of the same process can be schematized by taking into consideration two dimensions: the state of the internal process and the state of the external environment, as can be seen in chart no. 2 


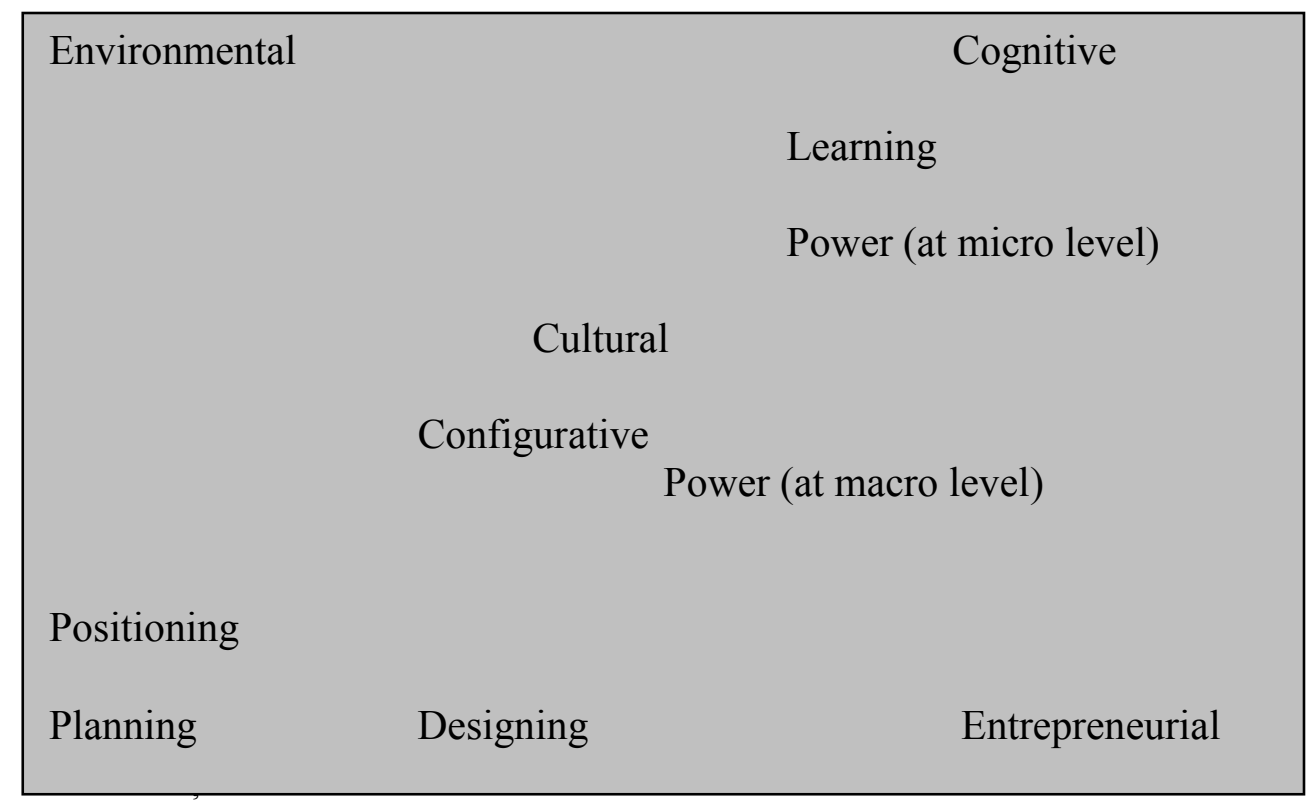

THE INTERNAL PROCESS

Chart no. 2. Formulating the strategy by using more processes (source: H. Mintzberg, J. Lampel, J.B. Quinn, S. Goshal, The Strategy Process, Fourth Edition, Pearson Education International, 2003, p.28)

In this case, the practitioners can choose from the many processes or combine them in the most convenient way.

\section{Bibliography:}

1. R. Whittington - What Is Strategy?- and Does It Matter, 2nd Edition, Thomson Learning, Londra, 2001, p. 325

2. H. Mintzberg, J. Lampel, J.B. Quinn, S. Goshal, The strategy process, Fourth Edition, Pearson Education International, 2003, p.22-26

3. T.L.Wheelen, J.D.Hunger, Strategic Management and Bussiness Policy. Concepts and Cases, Tenth Edition, Pearson Education, Prentice Hall, New Jersey, 2006

4. K. Andrews, The concept of Corporate Strategy, Richard D. Irwin Inc., Homewood, Illinois, 1980

5. I.Ansoff, Stratégie et développement de l'entreprise, Paris, L'edition d'organisation, 1996 
